\title{
Islamic Academic Culture (Budai) as a Model of Sustaining Religious Education in a Global Era at Sultan Agung Islamic University Semarang, Indonesia
}

\author{
D Murwantono ${ }^{1}$, Nuridin ${ }^{2}$, Mubarok ${ }^{3}$ \\ \{1'didik.m@unissula.ac.id, ${ }^{2}$ nuridin@unissula.ac.id, ${ }^{3}$ mubarok@unissula.ac.id \} \\ ${ }^{1,2,3}$ Sultan Agung Islamic University Semarang, Indonesia
}

\begin{abstract}
Nowadays many Islamic higher education systems globally operate the backdrop of Islamic traditional values. With the growing competition in the global higher education marketplace, Sultan Agung Islamic University (UNISSULA) has offered the quality Islamic traditions, namely Islamic Academic Culture (BudAI). The main objective of this research is to know the influences of BudAI implementation toward the students' behaviors in a global era based on Islamic values and tenets. Hence this study is under a qualitative and quantitative research supported by an interdisciplinary approach, mainly education, culture and social. The qualitative ethnography was adopted to collect the primary data through the interview and observation. Questionnaires were added to take account the influences of teaching BudAI by using the quantitative model of regression. This study of BudAI model shows that the implementing of Islamic Academic Culture has given great contributions toward students' behaviors in facing the global era by maintaining their Islamic values to be the generation of Khaira Ummah.
\end{abstract}

Keywords : BudAI, Teaching Model, Culture, Islamic Values

\section{INTRODUCTION}

The existence of global culture in the $21^{\text {st }}$ century that changes so quickly, is undeniably true. The change of life or work can be resulted from the automation economy because of the existence of the fourth industrial revolution (4IR) [1]. In facing this situation, UNISSULA must respond it wisely. There are only two choices - "to be or not to be" based on what the values from the changes are. At least, four points, such as growth, renewal, change, and continuity are to be prominent factors for filtering the values of the global era.

Then, what is globalization? If we see from the word, it can be defined from the verb " to globalize". It is closed to the meaning of "to make global", mainly to make worldwide in scopeacross borders and the spread of economical, political, cultural, and technological ideas. It is noted that in global era, at least only there is one domination culture. It is for nation who has great hegemony in all aspects of the life. Recently, two economical giants are America and China which dominate the position of global culture. 
Absolutely, America and China are to be a center of civilization. Their universities have also taken the top position of the world rank universities. In the tight competition among universities over the world, many developing and developed nations are looking for the uniqueness followed by the high quality of their universities.

At least, in Asia, the leaders of Higher Education must share a deep responsibility to prepare their graduates for the coming global competitions. They can increase the understanding of cultural diversity, the solidarity and regional integration within Asia, join research of Asian university, and increase the cooperation in Education [2].

UNISSULA also has done the same experiences with other universities for enhancing education in line with the spirit of era. Education will also be valueless without any reconstruction for the development of human resources as an agent of change. Furthermore, Sultan Agung Islamic University Semarang is one of the biggest Islamic Higher Education in Indonesia. In this era, accreditation is not the one criterion for guaranteeing any university in accumulating the new students. Most stakeholders, mainly from their parents are interested at UNISSULA Semarang, for an example, because of its uniqueness. UNISSULA not only offers the achievements, but also guarantees the religious behaviors. A research suggests that parents choose an Islamic university for their children because of high standards of conduct and behavior reflective of religious expectations [3]

The education program dealing with the religious activities at Sultan Agung Islamic University is familiarly called BudAI. It stands for 'Islamic Academic Culture.' It began in Agust 18, 2005 under Rofiq Anwar administration as the Rector. Then it becomes the main agenda of Islamic education for the next Rectors. As a program for enhancing education of Islamic traditional values, BudAI is run based on the characteristics of Unissula's cultural denomination. It is Islam. And Unissula has a powerful commitment as an Islamic Higher Education for running the program of BudAI with the Islamic spirit since the first time of the independence was promoted [4]

Hence, UNISSULA has agenda for implementing the program of BudAI per semester with training and education. In fact, it is not merely about the program but it is about that BudAI can be a part of tradition. So UNISSULA has roles for implementing, controlling, an enhancing the program. It is like a culture. Furthermore, the culture of education is very important in continuing tradition [5]. Tradition can be achieved by doing the activities many times till we find them as a part in our life that their existences are a must.

Hence BudAI is closed to the program of school culture. This model is mostly adopted by Madrasah (Senior Islamic School). Many authors have investigated the research studies on Madrasahs ( [6]; [7]; and [8]). They describe some the growing of Madrasahs along with the type of strategy education in school. Moreover in Madrasah, islamic values always are used for the main materials in the process teaching learning as a path of education [9]. In contrast to Madrasah, BudAI as the novelty of this research offers high-quality education method with the conceptual Founding to achieve the good character as a part of 'Khaira Ummah' new generation. This program has been supported fully by the Foundation of YBWSA (Council of Islamic Sultan Agung Foundation).

Khaira Ummah' has been popular at Sultan Agung Islamic University (UNISSULA) since Dr. dr Rofig Anwar's administration. The best generation reflected in the term of 'Khaira Ummah' finally refers to the good characters. They are inspired by high priority in the Prophet Muhammad (bless on him) standard, strong and positive university culture in the spirit of Islam, dignified 
conduct in classrooms or in UNISSULA's environment and principled and healthy interpersonal relations [10]

Moreover, UNISSULA has challenged for creating any strategy of education in this global era. Absolutely, it brings new changes in many aspects of life, mainly a lifestyle. In this sense, Islam education searches for developing and shaping the Muslim individual, society, and the entire Muslim Ummah. Hence this objective of this research is to examine the Moslem students' behaviors dealing with the existence of global culture around them by introducing of BudAI movements as a part of UNISSULA's cultural traits [11].

\section{RESEARCH METHOD}

As humans, we are always interpreting. They are the subject of living in this universe creating culture. The abilities of humans in creating and developing culture, according to the philosopher Ernst Cassirer because human beings are as 'animal symbolicum.' [12]. Because culture is a kind of symbolic system, the process of understanding any culture must be read, translated, and interpreted [13]. Research is also no different. Whether explicitly stated or not, all researches are guided by theoretical orientations or ways of interpreting the world that we call paradigm which widely recognizes two major paradigms -qualitative and quantitative [14].

This research is under quantitative and ethnography qualitative research supported by an interdisciplinary approach of American Studies. It is merely about the data. The qualitative researcher can get a better understanding of a specified phenomenon by demanding participants who have certain characteristics [15]. Thus this kind of research needs purposive sampling by selecting participants with specific characteristics, such as extreme cases, typical cases, maximum variation, or politically important cases [16]. Meanwhile the reconciliation of tense highlights on the concept of Founding And the interdisciplinary approach uses religion, sociology, and culture discipline.

Population and sampling in this research are from all elements of people in the YBWSA, meanwhile sampling is taken from every group, both lecturers and students in the environment of Sultan Agung Islamic University. Those data were taken in April 2019. But the participants for this research were selected-academic community in UNISSULA. They were students at both Faculty of Laws and Faculty of Language and Science of Communication. At least, there were two waves for getting completed data from all respondents. The total of complete data were 85 from 100 questionnaires. In this research, the dependent variable was "The Noble Character" (Y), meanwhile "BudAI Model (X)" was as the independent variable. Hence T-Test in linear regression analysis was used to know whether $\mathrm{X}$ has significantly influenced the dependent variable of $\mathrm{Y}$. Building on the research described above, our hypotheses as follows:(Ho) : There is no influence from $\mathrm{X}$ to $\mathrm{Y}$ partially; (Ha) : There is influence from $\mathrm{X}$ to $\mathrm{Y}$ partially. And the decision is $(\mathrm{Ho})$ will be rejected if the significance has the scores $(<0.05$, there is any influence) but if the significance is more 0.05 , (Ho) will be accepted (There is no influence partially)

This research was also under qualitative supported by an inter-disciplinary approach [17]. This approach was used to analyze the issue of Islamic Academic Culture from multidisciplinary perspectives, mainly Islamic education, social, and culture. Islam is specially chosen because Islam itself is phenomenon. In Islam, beliefs are of the first importance. Moreover, BudAI is noted as a long journey of belief accepted by all members of UNISSULA for achieving the good character. 
BudAI also involves theory of culture and theory of Conceptual Founding. Here, social life requires common habits, norms and values, as well as common beliefs and ideas, and that all these constitute culture. Meanwhile, nowadays a Higher Education has to respond toward the shifting global economy and technology. It is a must for any university to struggle for fighting against the fast changing of technology. One of them is by having the uniqueness.

\section{RESULT AND DISCUSSION}

BudAI was first divided into in number of movements. Respondents were the students in two faculties. They were totally 100 respondents, but 15 respondents were excluded because of uncompleted-documents. This research focused on five movements dealing with BudAI programs, such as (1). Prayer together movement, The students were called for the congregational prayers together both 'Dzuhur and 'Ashar' along with Dhuha (if it necessary) while they were in Campus; Furthermore, they could do the correct prayer (Sahiihul "Ibaadah). The Prophet was told to establish prayer and to see that members of household too did the same; (2) Islamic Dress Movement, the students were asked to dress as desired by religion. Here the obvious outward sign of modesty is the protection of one's private parts from any exhibition; (3) Tahaarat movement, It is closed to the meaning of purify and it is an essential feature of civilized life; (4) Modelling movement, it is merely about on how to imitate. It is here that the Prophet stands out among all the moral teachers of the world as all that he preached he also practiced, and we know all about it as recorded in Alhaadith; (5). Reciting Al Qur'an together movement. The Students were imposed to run the spirit of Iqra' hence the could open the world by knowledge.

Those movement have been implemented in UNISSULA as a part of education strategy. Education is also an attempt to help or assist the development of the social individual human beings, creatures of moral and religious beings [18] (Nasir, 2005:71). UNISSULA with its vision and mission brings about Islamic education in the spirit of "Bismillah Membangun Generasi Kahira Ummah" which is reflected in QS. Ali-Imron: 110 "We are the best of peoples, evolved for mankind, enjoining what is right, forbidding what is wrong, and believing in Allah. If only the People of the Book had faith, it were best for them: among them are some who have faith, but most of them are perverted transgressors".

Al-Ghazali said that 'amr al-ma 'rüfnahy al-munkar' is the largest matters in religion. The term denotes to activities commanding the good and forbidding the evil. At least we can do it started from our family. Humans always make mistakes. Hence it is something that is very principal, And because of that mission, God directed the prophets.

The concept of Founding is positioned to the Prophet Muhammad SAW as an ideal type [19]. Islam also knows the concept of 'taqlid' mainly the imitating on the loved ones. It is any kind of tradition. It is nothing more than the concrete experience of this truth which is carried in common by the society [20]. In short, the Islamic values are the premises of resistance to change and protection of past values. It is similar to the conservative values, mainly they will keep their traditional values that bring the better future. In Islam, the central theme is the seeking of the pleasure of God in whatever one does or believes. Anything which displeases God is bad and must be avoided strictly. Islam believes that everything that pleases God is also good for society and is in accord with the best in human understanding. 
Here it is the result of quantitative research only focusing on classical linear regression assumptions by seeing the residuals. From the data that we have got it by giving questionnaires to students in two faculties, we have plotted the residuals for the data set against $\mathrm{X}$ and the predicted values, $\mathrm{Y}$ that would give us basically the same picture with just a different scaling on the $\mathrm{X}$-axis. But we can not plot the residuals against the observed values of $\mathrm{Y}$ because they are related. It is noted that the residuals always sum to 0 in simple linear regression. What we are hoping to see is simply a random scattering of points. It means that nothing giving any indication that the assumptions of our model (picture 1) are false. It indicates that the BudaI implementation has any influence partially toward the good character for students in two faculties. See the picture 1.

Picture 1. Scatteplot

Dependent Variable: The Noble Character

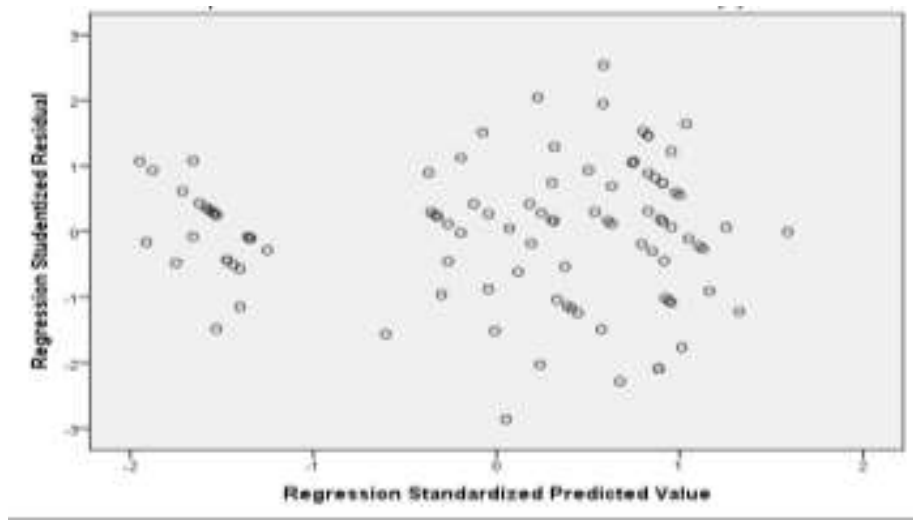

And the last destination for implementation this program is to be good characters inspired by the Prophet. How long has the program of BudAI been implemented? It is not a big deal. Finally it had better that there is controlling, continuity, sustainability, and enhancing the program. Hence this program can be alive like any tradition [21].

\section{CONCLUSIONS}

Having discussed the research above, it concludes that two faculties both the Faculty of Laws and the Faculty of Language and Science of Communication can accept the program of BudAI. It shows that there is a partial influence of the BudAi program to students' behavior based on Islamic values, such as prayer together, Islamic dress, taharaat, modeling and reciting the holy Al Qur'an. Even though, it is not significant influence, but UNISSULA has started introducing Fazail-iAkhlaaq - good morality. It is of the essence of the Prophet's teachings that salvation for mankind depends, on the one hand, on Imaan, and the other hand, on pious and good deeds- 'Aamal-iSwaleh. The BudAI is an strategy education as well as a UNISSULA's character in promoting, competing, and involving the relationship among the universities in a global competition. Furthermore, it also gives the strengthening of the spiritual world to run the civilizing movements 
as stated above and builds the reconstruction of science and technology as a part of a modern society in Industrial revolution point 4.0.

\section{REFERENCES}

[1] N. W. Gleason, Higher Education in the Era of the Fourth Industrial Revolution. Singapore: Springer Nature Singapore, Ltd., 2018.

[2] L. M. Kamaluddin, “'Asia Education Market: Trends \& Vision.' Campus IX Convention and Annual Metting of Rector Forum VI in UNISSULA," Semarang, 2013.

[3] I. Donohue Clyne, Seeking Education: The struggle of Muslims to educate their children in Australia. Melbourne: University of Melbourne., 2000.

[4] D. Muhammad, 40 Tahun Unissula: Antara Subyek dan Predikat. Buku Kenangan 40 Tahun Unissula. Semarang. Semarang: Sultan Agung Press, 2002.

[5] I. S. Wekke, "Arabic Teaching and Learning: A Model from Indonesian Muslim Minority," Procedia - Soc. Behav. Sci., vol. 191, pp. 286-290, 2015.

[6] D. S. Marbun, "Regional Autonomy and Its Impact on Madrasah Education.," in Proceedings of the 3rd Annual Conference Syiah Kuala University (AIC Unsyiah), 2013, pp. 61-64.

[7] H. Gamal, A. Nasir, and H. Zakaria, "The Role of I.A.I.N. In The Education System Reform of t he 'Madrasah, ," Am. Int. J. Contemp. Res., vol. 2, no. 5, pp. 87-95, 2012.

[8] A. Anwar, "Management of Madrasa: An Overview on Principals' Managerial Skills, Supervisors' Coaching Quality and Teachers' Performance," J. Pendidik. Islam, vol. 4, no. 1, p. 99, 2018.

[9] M. Abdullah, "School culture to serve performance of Madrasah in Indonesia," Qudus Int. J. Islam. Stud., vol. 7, no. 1, pp. 71-100, 2019.

[10] D. and O. A. Chown, "Toward Authentic Behavio Management Models for Islamic SchoolsA Framework Synthesizing Research," in 5th Annual ISNA West Coast Education Forum, 2016.

[11] A. M. Zedan, M. Y. Z. B. M. Yusoff, and M. R. Bin Mohamed, "An Innovative Teaching Method in Islamic Studies: The Use of PowerPoint in University of Malaya as Case Study," Procedia - Soc. Behav. Sci., vol. 182, pp. 543-549, 2015.

[12] E. Cassirer, An Essay on Man. U.S.: Yale University Press 1944, 1944.

[13] A. Kuper, Culture: The Anthropologists' Account. Cambridge: Harvard University Press, 1999.

[14] K. and R. E. W. Cooper, Qualitative Research in the Post-Modern Era: Contexts of Qualitative Research. New York: Springer Dordrecht Heidelberg., 2012.

[15] D. R. et al. Gehart, "Qualitative Research in Family Theraphy: A Substantive and Methodological Review," J. Marital Fam. Ther., vol. 27, no. 2, pp. 261-74, 2001.

[16] G. . Lincoln, Y.S. \& Guba, Naturalistic Inquiry. Baverly Hills, CA: Sage, 1985.

[17] H. N. Smith, Studies in American Culture. USA: University of Minnesota., 1980.

[18] R. Nasir, Mencari Tipologi Format Pendidikan Ideal. Yogyakarta: Pustaka Pelajar, 2005.

[19] M. Weber, The Protestant Ethic and the Spirit of Capitalism. Glencoe: The Free Press., 1961.

[20] C. W. Dunn, The Conservative Tradition in America. Lanham: Rowman \& Littlefield, 1996. 
[21] K. Saddhono, N. E. Wardani, and C. Ulya. "Sociopragmatic approach on discourse structure of friday prayer's sermon in java and madura island." J. of Lang and Lit, vol. 6 no. 1 pp 26$29,2015$. 